\title{
Kecernaan In Vitro Fraksi Serat (NDF, ADF dan Selulosa) Lima Jenis Rumput Laut Coklat dari Pantai Sungai Nipah Kabupaten Pesisir Selatan Sumatera Barat
}

\section{In Vitro Degradation of Fiber Fraction (NDF, ADF and Cellulosa) of Five Spesies of Brown Seaweeds from Sungai Nipah Beach Kabupaten Pesisir Selatan West Sumatra}

\author{
Y.L. Dewi ${ }^{1}$, R. Herawati ${ }^{2}$ dan M.E. Mahata ${ }^{2 *}$ \\ ${ }^{1)}$ Departement of Agriculture, Animal Science Center, Post Graduade of Andalas University, Padang \\ ${ }^{2)}$ Departement of Animal Nutrition and Technology, Faculty of Animal Science Andalas University, Padang \\ *Correspondent author: mariamahata@gmail.com \\ (Diterima: 2015; Disetujui: 2015)
}

\begin{abstract}
ABSTRAK
Penelitian ini bertujuan untuk mengetahui kecernaan fraksi serat (NDF, ADF dan Selulosa) lima jenis rumput laut coklat dari Pantai Sungai Nipah Kabupaten Pesisir Selatan Sumatera Barat secara in vitro. Metode penelitian yang digunakan adalah metode eksperimen dengan Rancangan Acak Kelompok (RAK) terdiri dari lima perlakuan rumput laut coklat yang berbeda jenis $(\mathrm{A}=$ Padina australis, $\mathrm{B}=$ Turbinaria decurrens, $\mathrm{C}=$ Turbinaria murayana, $\mathrm{D}=$ Sargassum crassifolium dan E = Sargassum binderi) dan masing-masing perlakuan diulang 3 kali sebagai kelompok. Kelompok didasarkan atas tiga kali pengambilan cairan rumen kambing yang berbeda. Parameter yang diamati pada penelitian ini adalah kecernaan NDF, kecernaan ADF dan kecernaan selulosa. Hasil penelitian menunjukkan 5 jenis rumput laut coklat berpengaruh sangat nyata $(\mathrm{P}<0,01)$ terhadap kecernaan NDF, kecernaan ADF dan kecernaan selulosa. Hasil penelitian ini dapat disimpulkan bahwa rumput laut Sargassum crassifolium dan Sargassum binderi memiliki kecernaan NDF tertinggi (15,65\% dan 20,56\%) dan ADF tertinggi (15,43\% dan 17,80\%) dibandingkan dengan jenis rumput laut coklat lainnya.
\end{abstract}

Kata kunci : rumput laut coklat, kecernaan in vitro, NDF, ADF, selulosa

\section{ABSTRACT}

The aims of this study were to evaluat the degradation of fiber fractions (NDF = neutral detergent fiber, $A D F=$ acid detergent fiber and cellulose) of five spesies of brown seaweeds from Sungai Nipah Beach, Kabupaten Pesisir Selatan, West Sumatera by in vitro method. The experiment was designed in a Randomized Block Design with 5 treatments [different species of brown seaweeds ( $A=$ Padina australis, $B=$ Turbinaria decurrens, $C=$ Turbinaria murayana, $D=$ Sargassum crassifolium and $E=$ Sargassum binderi)] with 3 different rumens liquids as blocks. The measured parameters were degradation of NDF, ADF and cellulose. Results of this study showed that five different species of brown seaweeds very significantly $(P<0.01)$ influenced the $N D F, A D F$ and cellulose degradation. The best NDF and ADF degradation occurred in Sargassum crassifolium and Sargassum binderi, with the degradation rates for NDF were $15.65 \%$ and $20.56 \%$, respectively and the degradation rates for $A D F$ were $15.43 \%$ and $17.80 \%$, respectively.

Keywords : brown seaweed, in vitro degradation, $N D F, A D F$, cellulose

\section{PENDAHULUAN}

Kabupaten Pesisir Selatan Provinsi Sumatera Barat memiliki panjang garis pantai 278,200 km (BKPMP Sumbar, 2014) memiliki keanekaragaman hayati laut mulai dari keanekaragaman jenis ikan, moluska, crustacean, rumput laut dan komoditi perairan lainnya. Sebagai daerah yang memiliki garis pantai yang panjang dan memiliki keanekaragaman hayati, menyebabkan ekonomi 
masyarakat khususnya masyarakat nelayan di daerah Kabupaten Pesisir Selatan tergantung pada hasil laut seperti hasil perikanan, kerang dan rumput laut. Rumput laut merupakan salah satu hasil laut yang dimiliki Kabupaten Pesisir Selatan yang memiliki potensi besar tetapi belum digali secara optimal. Beberapa wilayah pantai di Kabupaten Pesisir Selatan (Tarusan, Painan, Sungai Nipah, Batang Kapeh dan Surantiah) sangat cocok sebagai habitat rumput laut karena sebagian dari wilayah ini terdapat terumbu karang yang disukai oleh rumput laut.

Rumput laut di daerah Pantai Sungai Nipah tidak dibudidayakan tetapi tumbuh dan berkembang secara alami tanpa ada pembudidayaan oleh masyarakat. Masyarakat di sekitar Pantai Sungai Nipah setiap minggu dapat mengumpulkan rumput laut kering sebanyak satu ton (Info dari nelayan di Pantai Sungai Nipah, 2014). Hasil pengamatan lapangan di perairan Pantai Sungai Nipah Kabupaten Pesisir Selatan (2014), terdapat lima jenis rumput laut yang berbeda dan tumbuh dominan di perairan tersebut, masyarakat menamai rumput laut tersebut dengan nama lokal Pariamun. Berdasarkan hasil identifikasi oleh Laboratorium Ekologi Hewan Jurusan Biologi FMIPA Universitas Andalas (2015), lima jenis rumput laut tersebut, yaitu Padina australis, Turbinaria murayana, Turbinaria decurrens, Sargassum crassifolium, dan Sargassum binderi.

Menurut Winarno (1990), pada umumnya rumput laut mengandung air antara $12,95-$ $27,50 \%$, protein $1,60-10,00 \%$, karbohidrat $32,25-63,20 \%$, lemak 3,5-11\%, serat kasar 3$11,40 \%$, dan abu $11,50-23,70 \%$. Selain itu rumput laut juga kaya akan asam lemak omega 3, vitamin, pigmen, memiliki aktifitas antioksidan dan anti bakteri. Berbagai penelitian mengenai rumput laut telah membuktikannya. Sebagaimana yang disebutkan oleh Mohd et al. (2000) yang menyatakan bahwa $G$. changii mengandung komposisi asam lemak tak jenuh yang tinggi (74\%), terutama asam lemak omega 3 dan $26 \%$ asam lemak jenuh (terutama asam lemak palmitat) dan juga memiliki kalsium dan zat besi yang cukup tinggi. David (2001) dan Becker (2004) melaporkan bahwa rumput laut, baik sebagai sumber lemak dan vitamin larut air serta pigmen seperti klorofil. Rumput laut coklat (Sargassum dentifebium) memiliki aktivitas anti bakteri (Rizvi and Shameel, 2004). Abdel-Wahab et al. (2006), ekstrak berbagai jenis rumput laut di Laut Merah, seperti Laurencia obtuse dan Coulerpa prolifera memiliki pengaruh nyata terhadap perlawanan fungi beracun AFBI yang berpengaruh terhadap pertumbuhan sel kanker di hati.

Kandungan serat kasar rumput laut bervariasi yang disebabkan oleh faktor musim, geografi tempat tumbuh, jenis, umur panen dan kondisi lingkungan (Kaehler dan Kennish, 1996, Ortiz et al., 2006, dan Dennis et al., 2010). Dari hasil penelitian oleh Applegate dan Gray (1995) didapatkan kandungan fraksi serat dari 3 jenis rumput laut coklat (Phaeophyceae) yaitu: 1) Ascophylum nodosum mengandung NDF 22,0\%; ADF $13,1 \%$; selulosa $0,4 \%$; hemiselulosa $8,9 \%$ dan lignin $6,2 \%$,2) Alaria esculenta mengandung NDF 9,9\%; ADF 8,5\%; selulosa 3,5\%; hemiselulosa $1,4 \%$ dan lignin $2,3 \%$, dan 3 ) Fucus vesiculosis mengandung NDF 21,3\%; ADF 12,6\%; selulosa 0,9\%; hemiselulosa $8,7 \%$ dan lignin $6,1 \%$.

Rumput laut dapat digunakan sebagai bahan campuran pakan ternak, khususnya di negara-negara maritim (Rasyid, 2004). Rumput laut sebagai bahan pakan ternak di Indonesia belum digunakan secara optimal. Paterson et al. (1982), menyatakan bahwa ternak domba Orkney di North Ronaldsay Islands mengkonsumsi rumput laut coklat terutama jenis Laminaria sebagai pakan diet dan pakan utama. Di Teluk California rumput laut coklat jenis Sargassum digunakan sebagai pakan alternatif pada musim kemarau untuk memenuhi gizi ternak ruminansia (GojonBaez et al., 1998 ; Marin et al., 2009).

Berdasarkan uraian di atas rumput laut mempunyai potensi sebagai pakan ternak karena ketersediaannya yang melimpah dan mengandung nutrisi yang lengkap. Informasi kualitas nutrisi suatu bahan pakan ternak dapat diperoleh dari kecernaan fraksi serat secara in 
vitro. Teknik in vitro (teknik Tilley dan Terry) merupakan salah satu metoda evaluasi bahan pakan ternak yang menggunakan analisa kimia di laboratorium (AOAC, 1984), digunakan untuk memprediksi apa yang terjadi pada proses pencernaan sebenarnya pada ternak ruminansia (Ismartoyo, 2011). Metoda ini menirukan proses yang terjadi di dalam saluran pencernaan ruminansia (Ismartoyo, 2011).

Sejauh ini belum ada analisa kecernaan/laju degradasi fraksi serat (NDF, $\mathrm{ADF}$, dan selulosa) lima jenis rumput laut coklat (Padina australis, Turbinaria murayana, Turbinaria decurrens, Sargassum crassifolium dan Sargassum binderi) dari Pantai Sungai Nipah Kabupaten Pesisir Selatan secara in vitro, oleh sebab itu dilakukan penelitian ini untuk mengetahui kecernaan fraksi serat rumput laut tersebut.

\section{METODE}

\section{Materi Penelitian}

Penelitian ini menggunakan bahan: 1) lima (5) jenis rumput laut yang berbeda dari Pantai Sungai Nipah Kabupaten Pesisir Selatan yang terdiri dari Padina australis, Turbinaria murayana, Turbinaria decurens, Sargassum crassifolium dan Sargassum binder; 2) cairan rumen kambing sebagai sumber mikroba; zat-zat kimia yang digunakan untuk analisa Van Soest dan 3). larutan Mc Dougall's sebagai buffer. Peralatan yang digunakan: 1). timbangan Ohaus kapasitas 2610 gram; 2). peralatan in vitro seperti kain kassa, erlemeyer, tabung reaksi, gelas ukur dan shaker waterbath dan 3). alat untuk analisa Van Soest.

\section{Metode Penelitian}

Penelitian ini merupakan metode eksperimen, yaitu analisa kecernaan/laju degradasi fraksi serat (NDF, ADF, dan selulosa) dengan teknik in vitro (teknik Tilley dan Terry) menggunakan Rancangan Acak Kelompok (RAK) dengan 5 perlakuan yaitu: 5 jenis rumput laut dan 3 kali ulangan dalam bentuk blok untuk setiap pengambilan cairan rumen. Peubah yang diamati adalah 1) kecernaan neutral detergent fiber (NDF), 2) kecernaan acid detergent fiber (ADF) dan 3) kecernaan selulosa.

Data yang diperoleh dianalisis dengan sidik ragam. Jika terdapat perbedaan perlakuan, maka perbedaan antar perlakuan diuji dengan Duncan'n Multiple Rangel DMRT (Steel dan Torrie, 1991).

\section{HASIL DAN PEMBAHASAN}

\section{Kecernaan Neutral Detergent Fiber (NDF) dan Acid Detergent Fiber (ADF)}

Berdasarkan hasil penelitian pada Tabel 1 dapat dilihat rataan kecernaan NDF dan ADF dari lima jenis rumput laut coklat yang berbeda.

Hasil analisis keragaman menunjukkan bahwa jenis rumput laut coklat yang berbeda berpengaruh sangat nyata $(\mathrm{P}<0,01)$ terhadap kecernaan NDF dan ADF. Hasil uji lanjut DMRT pada kecernaan NDF dan ADF terlihat perlakuan A (Padina australis) berbeda tidak nyata $(\mathrm{P}>0,05)$ terhadap perlakuan $\mathrm{B}$ dan berbeda nyata $(\mathrm{P}<0,05)$ terhadap perlakuan $\mathrm{C}$ (Turbinari murayana), D (Sargassum crassifolium) dan E (Sargassum binderi). Perlakuan B (Turbinaria decurrens) berbeda tidak nyata $(\mathrm{P}>0,05)$ terhadap perlakuan A (Padina australis) dan berbeda nyata $(\mathrm{P}<0,05)$ terhadap perlakuan C (Turbinaria murayana), D (Sargassum crassifolium) dan E (Sargassum binderi). Perlakuan C (Turbinari murayana) berbeda tidak nyata $(\mathrm{P}>0,05)$ terhadap perlakuan D (Sargassum crassifolium) dan berbeda nyata $(\mathrm{P}<0,05)$ terhadap perlakuan $\mathrm{A}$ (Padina australis), B (Turbinaria decurrens) dan E (Sargassum binderi). Perlakuan D (Sargassum crassifolium) berbeda tidak nyata $(\mathrm{P}>0,05)$ terhadap perlakuan C (Turbinaria murayana) dan E (Sargassum binderi) serta berbeda nyata $(\mathrm{P}<0,05)$ terhadap perlakuan A (Padina australis) dan B (Turbinari decurrens). Perlakuan E (Sargassum binderi) berbeda tidak nyata $(\mathrm{P}>0,05)$ terhadap perlakuan D (Sargassum crassifolium) dan berbeda nyata $(\mathrm{P}<0,05)$ terhadap perlakuan A (Padina australis), B (Turbinaria decurrens) dan C (Turbinaria murayana).

Kecernaan NDF dan ADF rumput laut jenis A (Padina australis) dan B (Turbinaria 
Tabel 1. Rataan Kecernaan NDF dan ADF Lima Jenis Rumput Laut Coklat (\%)

\begin{tabular}{lcc}
\hline \multicolumn{1}{c}{ Perlakuan } & Kecernaan NDF & Kecernaan ADF \\
\hline A (Padina australis) & $-11,54^{\mathrm{c}}$ & $-11,66^{\mathrm{c}}$ \\
B (Turbinaria decurrens) & $-14,61^{\mathrm{c}}$ & $-17,09^{\mathrm{c}}$ \\
C (Turbinaria murayana) & $9,28^{\mathrm{b}}$ & $8,96^{\mathrm{b}}$ \\
D (Sargassum crassifolium) & $15,65^{\mathrm{ab}}$ & $15,43^{\mathrm{ab}}$ \\
E (Sargassum binderi) & $20,56^{\mathrm{a}}$ & $17,80^{\mathrm{a}}$ \\
\hline \multicolumn{1}{c}{ SE } & 2,19 & 2,16
\end{tabular}

Ket : SE $=$ Standard Error

Superskrip yang berbeda pada pada kolom yang sama menunjukkan perbedaan nyata $(\mathrm{P}<0,05)$

decurrens) yang ditemukan pada penelitian ini bernilai negatif, hal ini menunjukkan bahwa NDF dan ADF kedua jenis rumput laut ini tidak dapat dicerna oleh mikroba rumen. Tidak dicernanya NDF dan ADF kedua jenis rumput laut ini dapat disebabkan oleh kandungan garam $(\mathrm{NaCl})$ pada rumput laut. Kandungan garam rumput laut jenis A (Padina australis) adalah $10,07 \%$ dan B (Turbinaria decurrens) sebesar 11,2\% (Laboratorium Non Ruminansia Fakultas Peternakan Universitas Andalas, 2015). Menurut Persson (1983), bahwa batas maksimum pemberian garam untuk ruminansia $0,5 \%$. Setelah dihitung kandungan garam masing-masing jenis rumput laut ini dengan berat sampel 2,5 g untuk in vitro dalam $250 \mathrm{ml}$ campuran larutan Mc Dougall's dan cairan rumen (4:1), didapatkan masingmasingnya adalah $0,23 \mathrm{~g}$ untuk Padina australis dan 0,24 g untuk Turbinaria decurrens, sedangkan toleransi mikroba rumen terhadap garam dalam $250 \mathrm{ml}$ campuran larutan Mc Dougall's dan cairan rumen (4:1) berdasarkan batas toleransi $0,5 \%$ dalam ransum diperoleh $0,01 \mathrm{~g}$ garam. Berdasarkan kandungan garam yang terdapat pada kedua rumput laut ini diduga menghambat aktivitas dan pertumbuhan populasi mikroba rumen, ataupun menyebabkan kematian mikroba selama in vitro. Dengan demikian kecernaan NDF dan ADF kedua rumput laut ini menjadi negatif. Pendapat ini didukung oleh Ghosh et al. (1981), bahwa garam $(\mathrm{NaCl})$ pada rumput laut akan menurunkan biodegradasi.

Faktor lain yang memungkinkan tidak tercernanya NDF dan ADF rumput laut jenis A (Padina australis) dan B (Turbinaria decurrens), yaitu senyawa polyphenol yang kuat, yaitu phlorotannin yang terkandung pada rumput laut. Phlorotannin menyebabkan terganggunya aktivitas dan populasi mikroba rumen dalam mendegradasi NDF dan ADF. Hal ini sesuai dengan pendapat Wang et al. (2008), bahwa phlorotannin rumput laut coklat berperan sebagai inhibitor yang kuat terhadap aktivitas mikroba rumen. Phlorotannin yang diisolasi dari Eisenia bicyclis memiliki kekuatan antidioksidan 10 kali lebih tinggi dibandingkan ascorbic acid dan $\alpha$-tocopherol (Gupta, 2011). Salosso (2007), menyatakan bahwa rumput laut jenis Padina australis menghasilkan zona hambat yang terbesar terhadap pertumbuhan bakteri Vibrio harveyi dibandingkan rumput laut jenis Sargassum $s p$ dan zona hambat Turbinaria $s p$ lebih besar dibandingkan Sargassum $s p$. Phlorotannin bersifat larut dalam air ketika tidak berikatan dengan asam alginat dan phlorotannin tidak dapat larut ketika berikatan dengan asam alginat. Sesuai dengan pendapat Adhi et al. (2010), bahwa phlorotannin merupakan komponen yang dapat larut dalam air. Phlorotannin rumput laut memiliki kemampuan untuk berikatan dengan asam alginat dan protein membentuk senyawa kompleks menjadi komponen dinding sel, sehingga komponen dinding sel bertambah.

Ikatan phlorotannin dengan asam alginat dan protein yang kuat berperan dalam aktivitas antimikroba. Hal inilah yang menyebabkan nilai kecernaan NDF dan ADF rumput laut A (Padina australis) dan B (Turbinaria decurrens) bernilai negatif atau tidak dapat dicerna. Sesuai dengan pendapat Schoenwaelder dan Clayton (1998); Arnold dan Targett (2003), bahwa phlorotannin 
menjadi komponen dinding sel rumput laut ketika terhubung dengan membran sel dan phlorotannin dikeluarkan dari sel dan membentuk senyawa kompleks dengan asam alginat. Koivikko (2008), menjelaskan bahwa kemungkinan hubungan antara dinding sel (asam alginat dan phlorotannin) adalah ikatan ester dan ikatan hemiacetal, kedua ikatan ini membentuk ikatan kovalen, hal inilah yang menjadikan dinding sel sulit untuk didegradasi. Didukung juga oleh Wang et al. (2011), yang menyatakan phlorotannin membentuk senyawa kompleks dengan protein dan menurunkan deaminasi asam amino, diikuti penurunan konsentrasi $\mathrm{NH}_{3}$ dengan peningkatan konsentrasi phlorotannin. Interaksi antara phlorotannin dan protein berperan penting dalam aktivitas antimikroba (Ahn et al., 2004). Phlorotannin menyerang protein mikroba dan menyebabkan inhibitor bagi mikroba (Gupta, 2011).

Selain faktor garam dan senyawa polyphenol phlorotannin, hal lain yang mungkin dapat menyebabkan tidak tercernanya NDF dan ADF rumput laut jenis A (Padina australis) dan B (Turbinaria decurrens) disebabkan oleh cairan rumen yang digunakan berasal dari kambing yang belum pernah ataupun terlatih mengkonsumsi rumput laut, dan mikroba yang terdapat pada cairan rumen kambing tersebut memerlukan waktu adaptasi untuk mencerna bahan pakan rumput laut untuk memenuhi kebutuhan dan perkembangbiakannya, sementara itu proses in vitro berlangsung selama 48 jam, diduga proses in vitro yang singkat ini belum cukup untuk proses adaptasi mikroba rumen tersebut, sehingga kemampuan mikroba dalam mencerna NDF dan ADF kedua rumput laut ini bernilai negatif atau tidak tercerna. Hal ini sesuai dengan teori Williams et al. (2013), bahwa domba North Ronaldsay yang telah terbiasa makan rumput laut memiliki mikroba yang spesifik untuk mencerna rumput laut, dimana mikroba rumen menghasilkan enzim untuk menghidrolisis polisakarida (alginat, fukoidan dan laminarin) dan selulosa rumput laut. Kemampuan mikroba mencerna serat larut (alginat, karagenan dan agar) terbatas
(Michel dan Macfarlane, 1996; Michel et al., 1996; Wang et al., unpublished data). Hal ini didukung oleh pendapat Church (1998), tipe mikroba berkembang dalam rumen adalah mikroba yang memiliki daya adaptasi terhadap kondisi ekosistem yang spesifik dari rumen.

Kecernaan NDF dan ADF yang bernilai negatif yang ditemukan pada penelitian ini juga ditemukan oleh Crampton dan Harris (1969) yang memperoleh rataan kecernaan ADF yang rendah (-), yaitu $-14,6 \%$ dalam penelitiannya. Penelitian tersebut mengenai recycle feses ternak sebagai pakan ternak sapi terhadap kecernaan bahan pakan tersebut secara in vivo. Kecernaan ADF yang rendah () disebabkan mikroba rumen belum beradaptasi dengan pakan tersebut.

Hal yang menarik dari penelitian ini adalah NDF dan ADF dari rumput laut jenis $\mathrm{C}$ (Turbinaria murayana), D (Sargassum crassifolium) dan E (Sargassum binderi) dapat dicerna, meskipun mengandung garam yang lebih tinggi dibandingkan rumput laut jenis A (Padina australis) dan B (Turbinaria decurrens). Hasil analisa kandungan garam di Laboratorium Non Ruminansia Fakultas Peternakan Universitas Andalas (2015), menunjukkan rumput laut jenis Turbinaria murayana mengandung kadar garam 13,08\%, Sargassum crassifolium $11,21 \%$ dan Sargassum binderi 12,24\%.

Setelah kandungan garam masingmasing rumput laut tersebut dikalkulasikan untuk 2,5 g sampel yang di in vitro dalam 250 $\mathrm{ml}$ campuran larutan Mc Dougall's dan cairan rumen (4:1), didapatkan masing-masingnya adalah $0,28 \mathrm{~g}$ garam yang terdapat pada Turbinaria murayana; $0,23 \mathrm{~g}$ garam yang terdapat pada Sargassum crassifolium dan $0,26 \mathrm{~g}$ garam yang terdapat pada Sargassum binderi, sedangkan toleransi mikroba rumen terhadap garam dalam $250 \mathrm{ml}$ campuran larutan Mc Dougall's dan cairan rumen (4:1) terhitung $0,01 \mathrm{~g}$ garam.

Kandungan garam pada ketiga jenis rumput laut ini telah melebihi toleransi kadar garam yang dapat ditoleransi oleh mikroba rumen, namun kandungan garam ketiga jenis rumput laut ini terlihat tidak menghambat 
aktivitas dan populasi mikroba rumen tidak seperti yang terjadi pada rumput laut Padina australis sehingga NDF dan ADF ketiga jenis rumput laut ini dapat dicerna. Kondisi ini sulit dipahami dan belum dapat dijelaskan lebih lanjut, sehingga perlu dilakukan pengkajianpengkajian tentang zat-zat lain yang mungkin terdapat pada ketiga jenis rumput laut tersebut yang diduga dapat menghalangi pengaruh garam yang tinggi terhadap mikroba rumen, sehingga tidak mengganggu kecernaan NDF dan ADFnya.

Pendugaan pengaruh adaptasi mikroba rumen terhadap rumput laut yang terjadi pada rumput laut Padina australis dan Turbinaria decurrens tidak terlihat pada rumput laut jenis C (Turbinaria murayana), D (Sargassum crassifolium) dan E (Sargassum binderi), sehingga NDF dan ADF ketiga rumput laut tersebut dapat dicerna.

Dilihat dari Tabel 1, rataan kecernaan NDF lebih tinggi dibandingkan dengan kecernaan ADF karena NDF memiliki fraksi yang mudah dicerna dalam rumen seperti hemiselulosa, sedangkan komponen yang terdapat pada ADF, yaitu: selulosa, lignin dan silika yang merupakan fraksi yang sulit dicerna (Hakim, 1992). Kecernaan NDF yang lebih tinggi dibandingkan kecernaan ADF juga disebabkan oleh bakteri selulolitik yang dapat mencerna selulosa dan hemiselulosa, sedangkan bakteri hemiselulolitik hanya dapat mencerna hemiselulosa, sehingga hemiselulosa lebih banyak dicerna dibandingkan selulosa. Pendapat ini didukung oleh Van soest (1982), yang menyatakan bahwa bakteri hemiselulolitik tidak dapat mendegradasi selulosa, sebaliknya bakteri selulolitik dapat mendegradasi hemiselulosa.

\section{Kecernaan Selulosa}

Berdasarkan hasil penelitian pada Tabel 2. dapat dilihat rataan kecernaan selulosa dari lima jenis rumput laut coklat yang berbeda.

Hasil analisis keragaman menunjukkan bahwa jenis rumput laut coklat berpengaruh sangat nyata $(\mathrm{P}<0,01)$ terhadap kecernaan selulosa. Hasil uji lanjut DMRT pada kecernaan selulosa terlihat perlakuan A (Padina
Tabel 2. Rataan kecernaan selulosa lima jenis rumput laut coklat (\%)

\begin{tabular}{lc}
\hline \multicolumn{1}{c}{ Perlakuan } & $\begin{array}{c}\text { Kecernaan } \\
\text { Selulosa }\end{array}$ \\
\hline A (Padina australis) & $53,94^{\mathrm{a}}$ \\
B (Turbinaria decurrens) & $-26,21^{\mathrm{b}}$ \\
C (Turbinaria murayana) & $-37,91^{\mathrm{b}}$ \\
D (Sargassum crassifolium) & $-54,09^{\mathrm{c}}$ \\
E (Sargassum binderi) & $-27,81^{\mathrm{b}}$ \\
\hline \multicolumn{1}{c}{ SE } & 3,93 \\
\hline
\end{tabular}

Ket : SE = Standar Error

Superskrip yang berbeda pada pada kolom yang sama menunjukkan perbedaan nyata $(\mathrm{P}<0,05)$

australis $)$ berbeda nyata $(\mathrm{P}<0,05)$ terhadap perlakuan B (Turbinaria decurrens), C (Turbinaria murayana), D (Sargassum crassifolium) dan E (Sargassum binderi). Perlakuan B (Turbinaria decurrens) berbeda tidak nyata $(\mathrm{P}>0,05)$ terhadap perlakuan $\mathrm{C}$ (Turbinaria murayana) dan E (Sargassum binderi) dan berbeda nyata $(\mathrm{P}<0,05)$ terhadap perlakuan A (Padina australis) dan D (Sargassum crassifolium). Perlakuan C (Turbinaria murayana) berbeda tidak nyata $(\mathrm{P}>0,05)$ terhadap perlakuan B (Turbinaria decurrens) dan E (Sargassum binderi) dan berbeda nyata $(\mathrm{P}<0,05)$ terhadap perlakuan $\mathrm{A}$ (Padina australis) dan D (Sargassum crassifolium). Perlakuan D (Sargassum crassifolium) berbeda nyata $(\mathrm{P}<0,05)$ terhadap perlakuan A (Padina australis), B (Turbinaria decurrens), C (Turbinaria murayana) dan E (Sargassum binderi). Perlakuan E (Sargassum binderi) berbeda tidak nyata $(\mathrm{P}>0,05)$ terhadap pelakuan B (Turbinaria decurrens) dan C (Turbinaria murayana) dan berbeda nyata $(\mathrm{P}<0,05)$ terhadap perlakuan A (Padina australis) dan D (Sargassum crassifolium).

Pada Tabel 2 dapat dilihat bahwa kecernaan selulosa tertinggi terdapat pada rumput laut jenis A (Padina australis) sedangkan kecernaan selulosa rumput laut jenis B (Turbinaria decurrens), C (Turbinatia murayana), D (Sargassum crassifolium) dan E (Sargassum binderi) bernilai negatif. Hasil ini sangat kontradiktif dengan kecernaan NDF dan ADF masing-masing rumput laut tersebut (Tabel 1). Kecernaan selulosa rumput laut 
jenis (Padina australis) seharusnya bernilai negatif karena kecernaan NDF dan ADFnya bernilai negatif, namun pada penelitian ini ditemukan kecernaan selulosa rumput laut jenis A (Padina australis) sangat tinggi, yaitu 53,94\%. Hal yang ditemukan pada penelitian ini juga sulit dipahami dan dijelaskan serta belum diketahui penyebabnya. Selulosa merupakan komponen NDF dan ADF yang sulit untuk dicerna oleh mikroba rumen. Sesuai dengan pendapat Hakim (1992), selulosa merupakan fraksi serat yang sulit dicerna. Pendapat ini didukung oleh Horn (2000), yang menyatakan bahwa selulosa pada rumput laut terletak pada dinding sel yang ditutupi oleh komponen struktural lainnya yang menyebabkan keterbatasan bagi enzim untuk mendegradasi selulosa.

Kecernaaan selulosa yang bernilai negatif pada rumput laut jenis B (Turbinaria decurrens), C (Turbinaria murayana), D (Sargassum crassifolium) dan E (Sargassum binderi) menunjukkan bahwa terjadi kenaikan selulosa pada residu sampel setelah melalui proses in vitro dibandingkan dengan sampel sebelum mengalami proses in vitro. Jika dikaitkan dengan pengaruh garam yang terkandung pada masing-masing rumput laut ini untuk kecernaan selulosa yang bernilai negatif sulit dijelaskan karena NDF dan ADF masing-masing rumput laut ini dapat dicerna.

Tidak tercernanya selulosa oleh mikroba rumen dan bertambahnya residu setelah proses in vitro, hanya dapat diduga disebabkan oleh faktor senyawa polyphenol, yaitu phlorotannin yang terkandung pada rumput laut. Phlorotannin rumput laut coklat yang mengganggu aktivitas dan populasi mikroba rumen. Sebagaimana penelitian oleh Wang et al. (2009), bahwa phlorotannin menghambat keseluruhan proses fermentasi secara in vitro dan mempengaruhi spesies mikroba tertentu. Dijelaskan lebih lanjut bahwa phlorotannin menghambat populasi bakteri selulolitik, tetapi meningkatkan bakteri non selulolitik. Rumput laut yang memiliki kecernaan selulosa bernilai negatif atau tidak dapat dicerna ini juga disebabkan oleh alginat dan selulosa yang berikatan dengan komponen struktural lainnya sehingga sulit didegradasi oleh mikroba rumen. Horn (2000), menjelaskan bahwa alginat pada rumput laut berikatan dengan dinding sel berkombinasi dengan komponen struktural lainnya seperti selulosa yang menyebabkan kesulitan bagi enzim untuk mendegradasi. Lebih lanjut dijelaskan bahwa selulosa pada rumput laut terletak pada dinding sel yang ditutupi oleh. komponen struktural lainnya yang menyebabkan keterbatasan bagi enzim untuk mendegradasi selulosa (Horn, 2000). komponen struktural lainnya yang menyebabkan keterbatasan bagi enzim untuk mendegradasi selulosa (Horn, 2000).

\section{KESIMPULAN}

Dari hasil penelitian ini dapat disimpulkan bahwa kecernaan selulosa tertinggi $(53,94 \%)$ terdapat pada rumput laut Padina australis. Rumput laut Sargassum crassifolium dan Sargassum binderi memiliki kecernaan NDF tertinggi $(15,65 \%$ dan $20,56 \%$, masing-masingnya), dan ADF tertinggi $(15,43 \%$ dan $17,80 \%$, masingmasingnya) dibandingkan dengan jenis rumput laut coklat lainnya.

\section{DAFTAR PUSTAKA}

Abdel-Wahab, M.A., Ahmed, H.H., Hagazi, M.M., 2006. Prevention of aflatoxin B1 initiated hepatotoxicity in rat by marine algae extracts. J. Appl. Toxicol 26:229238.

Ahn M. J., K. D. Yoon, S. Y Min, J. S. Lee, J. H. Kim, T. G. Kim, S. H. Kim, N. G. Kim, H. Huh, and J. Kim. 2004. Inhibition of HIV-1 reverse transcriptase and protease by phlorotannins from the brown alga Ecklonia cava. Biol Pharm Bull 27: 544-547.

Anggadiredja, J. T., A. Zatnika., H. Purwato., dan S. Istani. 2010. Rumput Laut: Pembudidayaan, Pengolahan, Pemasaran Komoditas Perikanan Potensial. Penebar Swadaya, Jakarta. 
Applegate, R.D., dan P.B. Gray. 1995. Nutritional value of seaweed to ruminants. Rangifer 15 (10): 15-18.

Arnold T.M. and N.M. Targett. 2003. To grow and defend: lack of tradeoffs for brown algal phlorotannins. Oikos 100: 406408.

Badan Koordinasi Penanaman Modal Provinsi Sumbar. 2014. Letak geografi. http://bkpmp.sumbarprov.go.id/statistik2/letak-geografis/. 19 Agustus 2014 (21.12).

Becker, W. 2004. Microalgae in human and animal nutrition. In: A. Richmond (ed.) Handbook of microalgal culture. Blackwell Publ., Oxford, UK, pp 312351.

Chojnacka, K., A. Saeid., Z. Witkowska and L. Tuhy. 2012. Active biologycal compound in brown seaweed. Open Conference Proceedings Journal. Hal : 20-28.

Crampton, E. E. and L. E. Harris. 1969. Applied Animal Nutrition 2nd Edition. L. H. Freeman and Co, San Francisco.

David, W., 2001. Overview of sea vegetable chemical composition. Available from: http//www. surialink.com.

Denis C., M. Morancais, L.I. Min, E. Deniaud, P. Gaudin, G. WielgoszCollin, G. Barnathan, P. Jaouen, J. Fleurence. 2010. Study of the chemical composition of edible red macroalgae Grteloupia turuturu from Brittany (France). Food Chemistry (119) 913917.

Gojon-Baez, H.H., D.A. Siqueiros-Beltrones and H. Hernandez-Contreras. 1998. In situ ruminal digestibility and degradability of Macrocystis pyrifera and Sargassum spp. in bovine livestock. Cienc. Mar 24 (4): 463-481.

Hagerman A.E., and L.G. Butler. 1978. Protein precipitation method for quantitative-determination of tannins. J Agric Food Chem 26: 809-812.

Hakim, M. 1992. Laju degradasi protein kasar dan organic Setaria splendida rumput lapangan dan alang-alang (Imperate cylindrical) dengan teknik in sacco. Skripsi. Fakultas Peternakan Institut Pertanian Bogor, Bogor.

Kaehler, S., dan R. Kennish. 1996. Summer and winter comparisons in the nutritional value of marine macroalgae from Hongkong. Botani Marina 39: 1117.

Koivikko, R. 2008. Brown alga phlorotannin improving and applying chemical methods. Painosalama Oy, Finlandia.

Marin, A., M.C. Valdes, S. Carrillo, H. Hernandez, A. Monroy, L. Sangines dan F. P. Gil. 2009. The marine algae Sargassum spp. (Sargassaceae) as feed for sheep in tropical and subtropical regions. Revista de Biologia Tropical 57(4): 1271-1281.

Mohd, H., C.C. Yen and C.Y. Ching .2000. Nutritional composition of edible seaweed Gracilaria changgi. Food Chem 68:69-76.

Ortiz J., N. Romero, P. Robert, J. Araya, J. Lopez-Hernandez, C. Bozzo, E. Navarrete, A. Osorio. dan A. Rios. 2006. Dietary fiber, amino acid, fatty acid and tocopherol contents of the edible seaweed Ulva lactuca and Durvillae antartica. Food Chemistry (99): 98-104.

Omar, H.H., H.M. Shiekh, N.M. Gugumjee, M.M. El-Kazan and A.M. El-Gendy. 2012. Antibacterial activity of extracts of marine algae from the red sea of Jeddah Saudi Arabia. African Journal of Biotechnology 11(71): 13576-13585.

Paterson, I.W., dan C.D. Coleman. 1982. Activity patterns of seaweed eating sheep on North Ronaldsay, Orkney. Appl. Anim. Ethol 8 (1/2): 137-146. 
Rasyid, A. 2003. Karakteristik natrium alginat hasil ekstraksi Sargassum polycystum. Seminar Ritek Kelautan Nasional. Jakarta. 30-31 Juli.

Rizvi, M.A. and S. Shameel. 2004. Studies on the bioactivity and elementology of marine algae from the coast of Karachi, Pakistan. Phytotherapy Res 18: 865-872.

Schoenwaelder, M.E.A and M.N. Clayton. 1998. Secretion of phenolic substances into the zygote wall and cell plate in embryos of Hormosira and Acrocarpia (Fucales, Phaeophyceae). J Phycol 34: 969-980.

Suparjo. 2010. Analisis Bahan Pakan secara Kimiawi: Analisis Proksimat dan Analisis Serat. Fakultas Peternakan Universitas Jambi Press, Jambi

Stell, R.G and J.H. Torrie. 1991. Prinsip dan Prosedur Statistika. Suatu Pendekatan Biometrik. ed.2, cet. 2. Alih Bahasa B. Sumantri. P. T. Gramedian Pustaka Utama, Jakarta.

Van Soest, P.J. 1982. Nutrition Ecology of the Ruminant. Comstock Publishing House PVT,LTD, New Delhi.
Wang, Y., Z. Xu., S.J. Bach and T.A. McAllister. 2008. Effect of phlorotannin from Ascophyllum nodosum (Brown Seaweed) on in vitro ruminal digestion of mixed forage or barley grain. Anim Feed Sci Technol 145: 375:395.

Wang, Y., and A. McAllister. 2011. Brown algae as a feed additive: nutritional and health impacts on ruminants-a review. Nova Science Publishers, Inc. New York.

Wang, Y., T.W. Alexander and T.A. McAllister. 2009. In vitro effect of prhlorotannin from Ascophyllum nodosum (brown seaweed) on rumen bacterial populations fermentation. Agriculture and Agri-Food Canada Researce Center.

Wei, C.C., H.S. Ling and W.C. Lee. 2011. Antibacterial activity of Sargassum potcystum C. Agardh and Padina australis Hauck (Phaeophyceae). Arican Journal of Biotecnology 10(64): 1412514131.

Winarno, F.G. 1990. Teknologi Pengolahan Rumput Laut. Pustaka Sinar Harapan, Jakarta. 